Article

\title{
Expert Knowledge and Perceptions about the Ecosystem Services and Natural Values of Hungarian Fishpond Systems
}

\author{
Péter Palásti ${ }^{1,2, *}$, Márton Kiss ${ }^{2,3}$, Ágnes Gulyás ${ }^{2}$ and Éva Kerepeczki ${ }^{1}$ \\ 1 Department of Hydrobiology, National Agricultural Research and Innovation Center-Research Institute for \\ Fisheries and Aquaculture, 5540 Szarvas, Hungary; kerepeczki.eva@haki.naik.hu \\ 2 Department of Climatology and Landscape Ecology, Faculty of Science and Informatics, University of Szeged, \\ 6720 Szeged, Hungary; kiss.marton@geo.u-szeged.hu (M.K.); agulyas@geo.u-szeged.hu (Á.G.) \\ 3 Centre for Ecological Research, Institute of Ecology and Botany, 2163 Vácrátót, Hungary \\ * Correspondence: palasti.peter@haki.naik.hu
}

Received: 8 July 2020; Accepted: 27 July 2020; Published: 29 July 2020

\begin{abstract}
In the past few decades, multiple theoretical studies have highlighted the diverse capabilities of freshwater fishpond systems in the provision of water-related ecosystem services (ESs). However, practical studies to confirm this statement are still lacking in the scientific literature compared to other ecosystems. In this paper, we reveal the ESs of three semi-intensively managed fishpond systems in Hungary and assess the knowledge and perceptions of local experts about them and their main interactions. Between 2017 and 2019, we performed participatory research on the fishpond systems of Biharugra, Akasztó, and Szeged, conducting a total of 22 structured interviews with experts from all related stakeholder groups. Based on the interviews, we identified 16 actively used ESs (4 provisioning, 7 regulating, and 5 cultural ESs) and also revealed 19 main forms of impacts (14 positive and 5 negative) related to them. Despite their different perceptions and demands associated with fish farms, almost every expert articulated the role of semi-intensive fish farming in the sustenance of water-related natural values and ecosystem services, endangered by the ongoing effects of global warming. Besides confirming the theoretical statements of previous studies, these findings could also provide information for subsequent land-use planning, with the aim of creating more sustainable, multifunctionally used fishpond systems.
\end{abstract}

Keywords: ecosystem services; ES impacts; sustainability; freshwater fishpond system; semi-intensive aquaculture; participatory research; Hungary

\section{Introduction}

Based on the definition of the Food and Agriculture Organization (FAO), aquaculture is the organized rearing, feeding, propagation, or protection of aquatic resources (fishes, crustaceans, molluscs, aquatic plants, algae, etc.) for commercial, recreational, or public purposes [1]. Aquaculture has developed rapidly over the last 50 years and today, it is one of the fastest growing primary production sectors worldwide [2], providing more than $64.2 \%$ (approximately 54.4 million tons) of the world's food fish supply [1] every year. For a long time, this sector was mostly known for its important productional function; however, after the events of the Millennium Ecosystem Assessment [3], a great variety of studies have been conducted to identify and characterize the ecosystem services (ESs) [3] of many different natural and artificial ecosystems around the world, including fishpond systems. Due to the immense work of scientists and different scientific platforms, such as the Intergovernmental Platform on Biodiversity and Ecosystem Services (IPBES) [4], more support has been produced for the idea 
that aquaculture is also able to ensure ESs far beyond its productional function and could provide alternative utilization options.

After recognizing its optional capabilities, the need for multifunctionality in aquaculture was articulated back in 2010, when the first guidelines (e.g., Ecosystem Approach to Aquaculture (EAA)), were created to support sustainability in this sector [5], based on the recommendations of the United Nations Convention on Biological Diversity [6]. The diverse potential of sustainable aquaculture was also confirmed by Willot et al. [7], who identified 41 different ESs from the list of the Common International Classification of Ecosystem Services (CICES) [8] that could be provided by these aquaecosystems [9].

The ongoing effects of global warming have also increased the importance of artificially managed fish farms [10], as natural wetlands have already lost 50\% of their original area in Europe and Central Asia [11,12] due to their sensitivity to the changing environmental conditions [13,14], severely threatening many water-related taxa (especially bird species). The area of fishpond systems, on the contrary, has remained more stable due to their continuous water level regulation (e.g., inundation, drainage, and water supply). In the last decades, farming ponds have also been highlighted as regional biodiversity hotspots, providing habitats and refuges for some of the most endangered wetland species [15-18]. In particular, Barange et al. [10] and Naylor et al. [19] have indicated that the only way to ensure the long-term function of fishpond systems as refuge areas is to enhance the sustainability in fish farming activities. The European Commission has also provided guidance on how aquaculture activities could be integrated within Natura 2000 to revitalize degraded wetlands [20,21]. The Natural Park of the La Brenne network in France, the Bahía de Cadiz Natural Park in Spain, and the Sado Estuary in Portugal are good examples of this coexistence [20].

In the scientific literature, plenty of articles could be found on the ES providing capabilities of marine aquacultures (or maricultures) and coastal fish farms [22,23]. On the contrary, studies about freshwater aquaculture's ESs have somehow remained scarce (e.g., [21,24-27]), and most of the existing articles are only focused on a few specific ESs [28].

To provide a better picture about freshwater aquaculture's ES capabilities, the main goal of this exploratory study is to present the actual ESs of three semi-natural fishpond systems in Hungary. Given the limited scientific information on this topic, the collection and characterization of ESs were based on the available knowledge of local experts [4], including stakeholders and decision-makers, who can provide information on ecosystem dynamics based on their personal experiences [29] that could support issues with missing data [30]. Integrating local needs and building on indigenous knowledge are also known to secure local participation and provide opportunities for achieving higher returns at lower costs [31].

Through participatory research [32,33], as recommended by the IPBES framework [4], between 2017 and 2019, structured interviews were conducted with representative experts from the major local stakeholder sectors (fish farming, nature conservation, water management, and tourism) of the semi-intensively managed fishpond systems of Biharugra, Akasztó, and Szeged, in order to reveal the ESs of the selected fishpond systems and characterize their main impacts and interactions [34]. We hypothesized that these fishpond systems could actually provide a great proportion of the $41 \mathrm{ESs}$ highlighted by Willot et al. [7], and also hypothesized that, despite their different demands and perceptions associated with fish farming, all stakeholder sectors would somehow confirm the ability of semi-intensive aquaculture to provide other water-related ESs besides fish production.

\section{Materials and Methods}

\subsection{Characteristics of Hungarian Aquaculture}

In Hungary, freshwater aquaculture is the dominant form of fish production due to the lack of maritime ecosystems. Farming activities mainly focus on the production of common carp (Cyprinus carpio), practiced in artificial, extensive pond systems. These systems usually consist of 
multiple, soil-based ponds with around 30-40 hectares and between 1 and $2 \mathrm{~m}$ deep [35]. Some bigger fishpond systems in Hungary have more than 2000 hectares. The water for these systems is supplied by canal networks, which also drain their effluents. In both cases, the flow of water is resolved gravitationally or with water pumps, depending on landscape and water level contexts.

Traditionally, it takes three years to create market-sized fish, and fish production is mainly based on the pond's natural food resources (algae and macroinvertebrates), enhanced by artificial manuring. Supplementary grain feeding is also applied for higher growth rates [36]. This management strategy can be generally considered as semi-intensive aquaculture [37,38]. Together with common carp, additional fish species are also raised in polycultures, such as European catfish (Silurus glanis), silver carp (Hypophthalmichthys molitrix), grass carp (Ctenopharyngodon idella), zander (Sander lucioperca), and northern pike (Esox lucius) [36]. In 2018, Hungary had 26,500 hectares of fishponds that produced approximately 22,500 tons of fish, around $80 \%$ of which was common carp [35].

\subsection{Characteristics of the Studied Fishpond Systems}

To identify the main ESs of semi-intensive fish farms, we selected three Hungarian fishpond systems, characterized by nature-friendly fish farming technics (Figure 1): The Biharugra fishpond system, the "Fehértó" of Szeged, and the Akasztó fishpond system. These three fishpond systems are part of the EU's Natura 2000 network, which has been created to maintain biodiversity through the preservation of habitats with high natural value. From a conservation point of view, the semi-natural freshwater habitats involved in this study are mostly known for their diverse avian fauna, which is a consequence of their role of providing rich feeding, resting, breeding, and wintering opportunities for multiple protected migratory and non-migratory bird species.

The Biharugra fishpond system is located approximately $200 \mathrm{~km}$ southeast of the Hungarian capital, close to the Romanian border ( $46^{\circ} 57^{\prime} 14.8^{\prime \prime}$ N 21 ${ }^{\circ} 37^{\prime} 11.6^{\prime \prime}$ E). It's nearly 2000 hectares [39] are divided into two separate units: The northeastern "Ugra" unit consists of 28 ponds ( $~ 500 \mathrm{ha})$, while the southwestern "Begécs" unit has 24 ponds ( 1500 ha) [39]. It is mainly surrounded by arable fields and small villages, but some protected meadows and marshes can be also found there. Currently, two semi-intensive fish farms are functioning there simultaneously (Figure 1).

The "Fehértó" (Whitelake) of Szeged is approximately $170 \mathrm{~km}$ southeast of Budapest $\left(46^{\circ} 20^{\prime} 15.3^{\prime \prime} \mathrm{N}\right.$ $\left.20^{\circ} 07^{\prime} 46.9^{\prime \prime} \mathrm{E}\right)$. This system is comprised of 2200 hectares and is divided into two distinct units: The northern part, known as the Old Fehértó, has 17 ponds ( 1350 ha), and the New Fehértó or "Fehértavi Fertô" has 16 ponds ( 650 ha). The "Fehértó" only has one functional fish farm and is surrounded by agricultural fields and urban areas (Figure 1).

The Akasztó fishpond system is located $100 \mathrm{~km}$ south of Budapest $\left(46^{\circ} 44^{\prime} 01.5^{\prime \prime} \mathrm{N} 19^{\circ} 10^{\prime} 20.1^{\prime \prime} \mathrm{E}\right)$. Compared to the other two systems, it is relatively small ( $\sim 1000$ ha) and cannot be divided into subregions. This fishpond system has 33 ponds altogether that are shared among three semi-intensive fish farms in a proportion of around 75, 20, and 5\%. Like the other systems, the Akasztó fishpond system is mostly surrounded by arable lands, but protected marshes and swamps are also represented there to a greater extent (Figure 1).

\subsection{Procedure of ES Collection}

To collect information on the ESs of the study fishpond systems, we contacted all of the major stakeholder groups related to the pond systems and conducted structured interviews [40] with their representative experts, known as "key-informants" [41] (who could also be stakeholders or decision-makers). The stakeholder groups were mainly identified by a pilot survey, but we also asked every expert to recommend other relevant groups or key-informants. Questions in our structured interview (Table S1) were previously tested on five experts from the field of aquaculture to reveal and correct any problems. Interviews started with a general briefing about ESs and the main purposes of our study. Here, we made an extra effort to avoid mentioning specific ESs, in order to guarantee that interviewees' answers to further questions were based on their own knowledge. After the 
introduction, we gave every expert a list of ESs, where we summed up the most plausible ESs provided by Hungarian aquaculture, based on the results of Kerepeczki et al. [42]. The application of a common list was necessary to avoid possible misunderstandings and different wordings of the interviewees. Based on their experiences, key-informants selected ESs from the list, including those provided by their pond system [27]. They were also allowed to suggest new ESs if they judged it necessary. In that case, we contacted all experts and asked them if the ES in question is also present in their fishpond system. In the list for each system, we only included those ESs which were highlighted by at least one key-informant. ESs were classified into the three categories of provisioning, regulating and maintaining, and cultural ESs, based on the Common International Classification of Ecosystem Services (CICES) [8]. To characterize the demands of the different stakeholder groups, key-informants were also asked to highlight the ESs that are important for their group, and to briefly justify their choices (Table S1). After the interviews, the number of times that an ES had been mentioned by an expert and the number of times that it had been highlighted as important were summarized and mean values (mean mentioning value (MMV) and mean importance value (MIV)) with standard deviations (SD) were calculated for the three ES categories to characterize the knowledge and demands of key-informants in different stakeholder sectors.
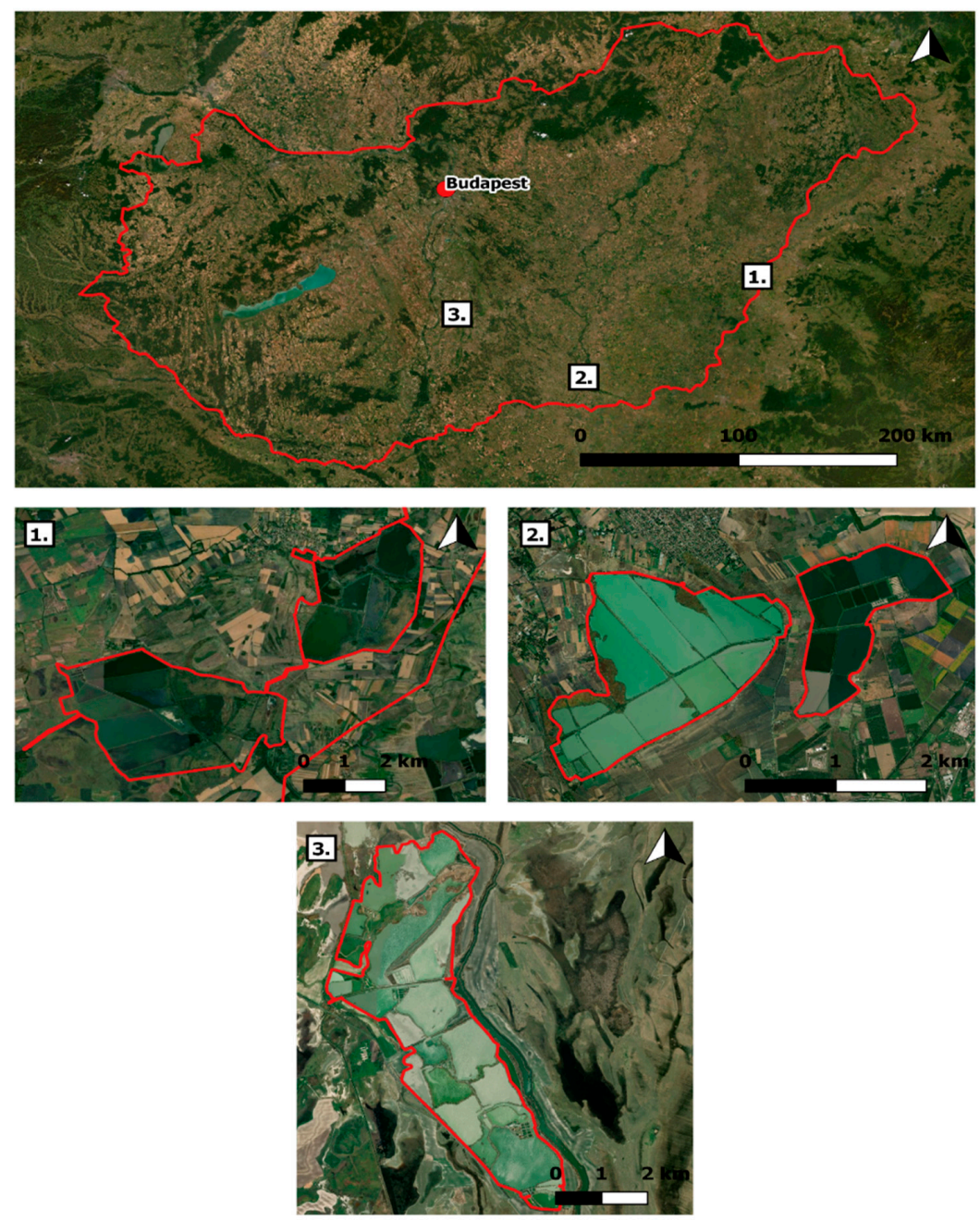

Figure 1. Selected fishpond systems and their location in Hungary: 1. Biharugra fishpond system; 2. Fehértó of Szeged; 3. Akasztó fishpond system (created with QGIS 2.18.10 (Open Source Geospatial Foundation, Chicago, IL, USA)). 
In general, interviews lasted 1-2 h. Answers were usually written, but additional sound recordings were also prepared for further analysis, with the permission of the key-informants. Our study complied with all of the ethical regulations of social research [43-45], in accordance with the Declaration of Helsinki. Subjects of the interviews also gave their informed consent before they participated in the study.

Between 2017 and 2019, we contacted 22 representative experts, including 12 from the fishpond system of Biharugra, 7 from Szeged, and 3 from Akasztó. Posterior feedbacks of the key-informants indicated that we had managed to cover every relevant expert and stakeholder group related to each fishpond system. Based on their interests in the fish farms, we categorized stakeholder groups into four sectors: Fish farming (fish farmers and fishermen) (FF); nature conservation (rangers of national park directorates and members of non-governmental organizations with conservational goals) (NC); water management (experts of governmental water management directorates) (WM); and tourism (owners of local hotels, recreational and educational centers, etc.) (T) (Table 1).

Table 1. The number of interviewed key-informants, organized by their related fishpond systems and stakeholder sectors.

\begin{tabular}{ccccc}
\hline Stakeholder Sectors & \multicolumn{4}{c}{ Fishpond Systems } \\
\hline & Biharugra & Szeged & Akasztó & Sum \\
\hline fish farming (FF) & 6 & 1 & 2 & 9 \\
nature conservation (NC) & 3 & 3 & 1 & 7 \\
water management (WM) & 0 & 2 & 0 & 2 \\
tourism (T) & 3 & 1 & 0 & 4 \\
sum & 12 & 7 & 3 & 22 \\
\hline
\end{tabular}

\subsection{Identifying ES-Related Impacts and Interactions}

In the second part of our structured interviews, experts were asked to describe any positive or negative impacts [34] that each of their previously mentioned ESs can have on the environment or other ESs on the list (Table S1), based on their previous observations. After the interviews, the impacts were summed up in a list and sent back to key-informants for proofreading. Based on the results, two-way interactions (trade-offs [46] and synergies [47]) were also identified and discussed with local experts.

\section{Results}

\subsection{Revealed ESs}

The results of the structured interviews revealed 16 different ESs (Table S2). Besides fish production, the group of provisioning ESs included reed production, feed for grazing livestock, and firewood. Listed regulating and maintaining ESs were microclimate regulation, carbon sequestration and storage, air quality regulation, water quality regulation, water storage, opportunity for water retention, and groundwater recharge. In the case of cultural ES aesthetics, cultural heritage/inspirational sources, opportunities for scientific research, opportunities for environmental education, and recreation were revealed. Recreation embodied multiple kinds of recreational activities, such as hiking, hunting, or fishing. Descriptions of the listed ESs above can be found in Table S2.

\subsection{The Knowledge and Perceptions of Key-Informants}

During our study, fish production (22), recreation (21), and cultural heritage/inspirational sources (17) gained the highest number of mentions across the fishpond systems (Figure 2a, Table S3), and cultural ESs were the most frequently selected ES category (MMV: $15.4 \pm 4.04$ ) (Table S4). Fish production (13) and recreation (14) was highlighted the most times as important ESs (Figure 2b). In this category, experts of FF mainly chose provisioning ESs (MIV: $3 \pm 3.37 \mathrm{SD}$ ), but they were also interested in water quality regulation (Figure 2b, Table S5). In NC, cultural ESs were preferred (MIV: 
$4 \pm 2.74 \mathrm{SD}$ ), but the importance of other types of ESs (e.g., reed production) was also occasionally highlighted (Figure 2b, Table S5). Experts of WM only highlighted opportunities for water retention, so regulating ESs appeared to be the most important ES group for them (MIV: $0.29 \pm 0.76 \mathrm{SD}$ ) (Figure 2b, Table S5). For the members of T, cultural ESs were the most significant (MIV: $1.4 \pm 1.67$ SD); however, they also pointed out fish production and carbon sequestration and storage quite frequently (Figure $2 b$, Table S5). Collectively, cultural ESs were highlighted the highest number of times as important ESs (MIV: $6.4 \pm 3.91 \mathrm{SD}$ ) (Figure 2b, Table S5), despite the different demands of the stakeholder groups. The results for each fishpond system are reported in the Supplementary Material (Tables S4 and S5).

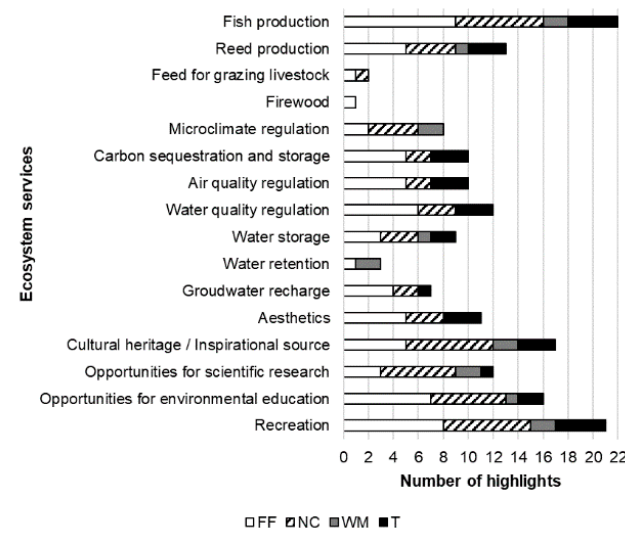

(a)

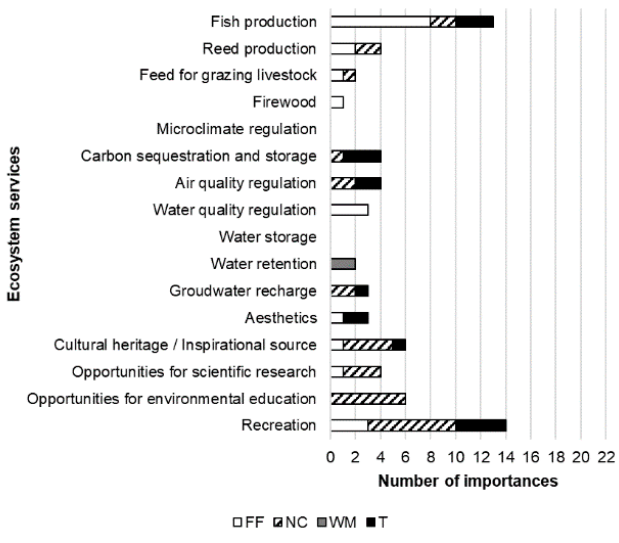

(b)

Figure 2. Knowledge and perceptions of key-informants: (a) The number of times when an ecosystem service (ES) was highlighted by the members of each stakeholder sector, where FF-fish farming, $\mathrm{NC}$-nature conservation, WM-water management, and T-tourism; (b) the number of times when an ES was highlighted as important for a stakeholder sector, where FF-fish farming, NC—nature conservation, WM-water management, and T-tourism.

\subsection{Main Impacts and Interactions Between ESs}

\subsubsection{Positive Impacts}

During the interviews, key-informants revealed 14 positive impacts related to the fishpond systems' ESs (Figure 3, Table S6). Almost all experts agreed that fish production has a central role in the provision of every other ES in our final list ("Well, essentially everything is related here ... all things remain as it is because of the fish production and the water needed for it, that's the base of all"). Based on the given answers, this role could be direct and indirect: First, 16 experts said that aquaculture is the primary reason for the existence and management of fishpond systems (Table S6). Without it, these systems and their ESs would disappear in a relatively short period of time. As one of our key-informants mentioned, "even the conservational activities are dependent on the fish farming! ... Without it, they just cannot be operated". The direct, positive contributions of fish farming to recreation, carbon sequestration and storage, and microclimate regulation were also highlighted separately by single key-informants. Indirect effects of fish production on other ESs were linked to the wildlife of the fishpond systems: Nine experts mentioned that semi-intensive aquaculture has a very positive effect on the water-related habitats and wild species of the fishponds, and could provide or enhance additional ESs as some kind of catalyzer ("the open, muddy surface of the drained ponds serves as a great feeding area for the birds"). Positive effects of the fishponds' wildlife communities were highlighted in five cases: Fish production, reed production, water quality regulation, recreation, and carbon sequestration and storage. Nine key-informants articulated that fish growth in semi-intensive aquaculture mainly depends on natural food sources (e.g., algae and macroinvertebrates), managed by manuring. Eight experts mentioned that the leftovers of this manuring and other polluting materials are mostly eliminated by 
the natural microbiota and reedy vegetation of the ponds. Healthy reed beds were also highlighted as great contributors to reed production (1 key-informant) and carbon sequestration and storage (1 key-informant), besides their ability to enhance recreational activities (e.g., hiking) with their heterogeneous avian fauna (6 key-informants). The only ES that was mentioned as a benefactor to the wildlife communities of the pond systems besides fish farming was the opportunity for grazing that keeps the vegetation of banks in a tended condition (1 key-informant) (Figure 3, Table S6).

Based on their personal experiences, two interviewees emphasized that recreational activities may raise the level of environmental education and scientific research, given the arriving visitors and tourists who could create reputations for the fishpond systems and their different values (Figure 3, Table S6).

Last, but not least, one key-informant noticed that the water storage function of the ponds has beneficial effects on microclimate regulation due to the raised levels of humidity and the heat absorption/emission of the water bodies that could regulate air temperature nearby the pond systems ("It cools in summer and heats in winter") (Figure 3, Table S6).

\subsubsection{Negative Impacts}

Key-informants revealed five negative impacts during our research that could occur between certain functions and ESs of fishpond systems (Figure 3, Table S7).

One impact in this category was particularly significant for all members of FF: The negative effects of wildlife communities on fish production. The most important factor here was the fish consumption by the great cormorant (Phalacrocorax carbo). As fish farmers explained, when assembling into big groups, cormorants could cause remarkable losses to fish farms, not just with their daily fish-eating activity, but also through the disturbance and injuries of valuable, market-sized fish. Experts also highlighted that current options for population control and damage prevention (e.g., sound cannons), suggested by the European Union, are not effective enough to mitigate the negative effect of cormorants and there is still no official way to call for compensation from the state or nature conservation agencies. From the fish farmers' point of view, two more taxa were mentioned as unpleasant, but far less maleficent guests in the area besides cormorants: Otter (Lutra lutra) and different seaweed species. The latter could cause damage to boat engines and create a great obstacle for fishing nets (Figure 3 , Table S7).

Three experts drew our attention to the possible negative impacts of reed production on fishponds' wildlife communities. As they explained, harvesting big, continuous areas without limitations could cause a great loss in natural values, mainly in terms of the avian fauna (" ... they (the birds) need those old, rancid fields of reed for living"). Fortunately, this problem was already recognized and managed by periodically changing harvesting mosaics and with a carefully selected working period (January-February) that does not disturb the breeding of protected bird species. Despite the regulations, one interviewee highlighted that reed production can also negatively affect the scientific research and monitoring activities of bird species if harvesting is implemented close to research areas (Figure 3 , Table S7).

Finally, recreation was highlighted as a factor that could harm fish production and the wildlife communities of fishpond systems through disturbance caused by tourists and visitors. These negative effects, however, were only mentioned by one key-informant, and they only occurred a few times (Figure 3, Table S7).

\subsubsection{Trade-Offs and Synergies}

Summarizing the answers of key-informants regarding the different impacts of each ESs revealed four types of trade-off and one type of synergy related to the fishpond systems' ESs. As is highlighted in Figure 3, recreation was found to be in a trade-off with fish production and with the fishpond systems' wildlife communities, as the presence of tourists could potentially disturb both fish farming activities and local fauna. Recreational opportunities, however, could provide a great source of income 
for FF, NC, and T, so stakeholders are continuously trying to maintain recreation on a moderate level, synchronizing the needs of every party. In the case of reed production and fish production, trade-offs with wildlife communities were also found, but as in the case of recreation, the moderate use of both ESs, taking the threshold of the fishpond systems' carrying capacity into account, was mentioned as a great way of avoiding most of the negative impacts. The only synergy occurred between fish production and wildlife communities (Figure 3), as multiple experts highlighted that fish growth in semi-intensive aquacultures is highly dependent on natural food sources (algae, macroinvertebrates, etc.) provided by the wildlife communities and mostly maintained by the fish farms.

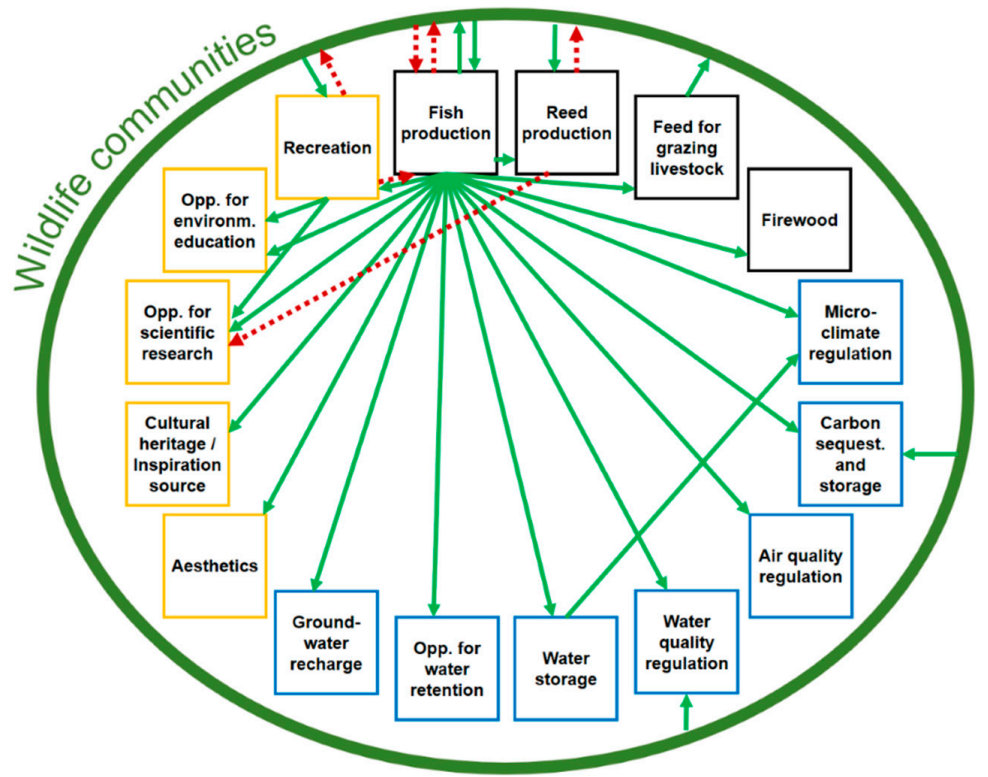

Figure 3. Impacts and interactions between the listed ESs revealed by key-informants (green circle around all ESs-fishpond systems' wildlife communities; black squares-provisional ES; blue square-regulating and maintaining ES; orange square-cultural ES; green arrows-positive impacts; red arrows with broken lines-negative impacts).

\section{Discussion and Conclusions}

Despite their productional function, freshwater aquacultures can be great examples of agricultural areas where environmentally friendly management allows the collaboration of nature and humanity, resulting in a great variety of ESs and natural values. Until now, however, no study has been implemented to confirm this statement by showcasing the full repository of fishpond systems' actual ESs. To provide more evidence on this topic, we conducted participatory research and assessed the knowledge and perceptions of 22 local experts related to three semi-intensively managed fishpond systems in Hungary. Our exploratory study confirmed the presence of 16 provisioning, regulating and maintaining, and cultural ESs that were all listed in the theoretical work of Chen et al. [48], and represented more than a third of the ESs that were highlighted in the summary of Willot et al. [7] for aquacultures.

In general, cultural ESs were the most mentioned ES category by all four stakeholder sectors represented in our study (Figure 2a, Table S4). This finding indicates that cultural ESs are commonly utilized and acknowledged throughout the assessed fishpond systems after fish production, despite the various demands of the different stakeholder sectors (Figure 2b, Table S5). During the interviews, representatives of the fish farming and touristic sectors often mentioned ESs from every ES category, while experts from the nature conservation and water management sector surprisingly showed a certain level of insecurity in the field of regulating and maintaining ESs (Figure 2a, Table S4). The main reason behind this could be the personal relationships between the experts and the fishponds, as all 
key-informants from fish farming and touristic sectors had close, often life-long relationships with fishpond systems, and their work was almost solely concentrated around them, which occurred less often for the experts of the other two sectors.

Based on their experiences, key-informants described a great variety of positive impacts related to the identified ESs and frequently highlighted the symbiotic relationship between semi-intensive fish production and water-related wildlife communities of the ponds, which, according to most of our local experts, is the main reason why these artificial habitats provide a great variety of ESs. Without fish farming, or any other type of active management, ponds would quickly transform into homogeneous reedy areas or shrubby meadows, depending on their water resupply, which would result in losses in both biodiversity and ESs [49]. On the other hand, wildlife communities were usually referred to as some kind of catalyzer that could enhance fish production (with natural feed) and the providing capabilities of the pond systems in all ES categories (Figure 3, Table S6), which is rarely mentioned in the scientific literature (e.g., [48]). Besides the previous advantages, a few negative impacts were also highlighted (Figure 3, Table S7). Most of them were described as potential effects only occurring only when the use of the available supplies exceeds the fishpond systems' carrying capacity (e.g., unsustainable level of fish farming, reed production, or tourism). To prevent these impacts, stakeholder groups are continuously reconciliating their plans and implementing them in agreement, considering the protected status of the pond systems. Despite their efforts, however, the damage of fish stocks, caused by fish-consuming bird species, such as the great cormorant (Phalacrocorax carbo), has still not been resolved and creates conflicts between fish farmers and nature conservation [50,51]. In the case of unrevealed ecosystems, such as fishponds, with a significant added value in the description of Social-Ecological Systems [52], the consideration of positive and negative impacts related to ESs is just as important as the revealed ESs themselves for avoiding costly trade-offs [53-55] and promoting the multifunctional use of landscapes [56-58].

Collecting and reconciling the knowledge and perceptions of experts by using participatory techniques is one of the first steps for the complete assessment of ESs [4] and also a key-element required for sustainable land use management $[53,54,59,60]$. Without it, conflicts might easily emerge between stakeholder groups with opposing preferences [60], which sometimes leads to the degradation of landscapes and ESs [61]. To prevent this, our study represents the knowledge of all local key-informants related to the three Hungarian fishpond systems in question. In some cases, stakeholder sectors consisted of only a few relevant key-informants, which did not allow us to compare the general perceptions of the stakeholder sectors. However, our main goal was not to provide quantitative data, but to characterize the ES providing capabilities of the selected fishpond systems by assessing the available information of all relevant experts with qualitative methods [54,62,63].

In this research, we have confirmed that semi-intensively managed freshwater fishpond systems in Hungary can ensure a great variety of ESs, including provisioning, regulating and maintaining, and cultural ESs, and we have also provided an insight into the impacts, interactions, and stakeholder demands that should be considered in the planning of land-use strategies. However, it is important to note that these results only represent the capabilities of semi-intensive fishpond systems and are not applicable in the case of extensive or intensive management.

Hungarian fishpond systems are still far away from fulfilling their full potential. With our results, we would like to pay more attention to freshwater aquacultures' ES providing capabilities and create a base for long-awaited, more quantitative analyses (e.g., [23]) (23) of these unique habitats, where, as one of our key-informants described, "every single day has its own miracle".

Supplementary Materials: The following are available online at http://www.mdpi.com/2073-4441/12/8/2144/s1: Table S1: Questions of the structured interviews; Table S2: Revealed ESs of the fishpond systems; Table S3: Number of times when the listed ESs were highlighted by the key-informants of the selected fishpond systems; Table S4: Mean mentioning values of the main ES categories, where FF-fish farming, NC—nature conservation, WM-water management, and T-tourism; Table S5: Mean importance values of the main ES categories, where FF-fish farming, NC—nature conservation, WM-water management, and T-tourism; Table S6: Revealed positive impacts related to the listed ESs with the number of times when they were mentioned by the members of 
each stakeholder sector of the selected fishpond systems. FF-fish farming, NC—nature conservation, WM-water management, and T-tourism; Table S7: Revealed negative impacts related to the listed ESs with the number of times when they were mentioned by the members of each stakeholder sector of the selected fishpond systems. FF-fish farming, NC—nature conservation, WM-water management, and T—tourism.

Author Contributions: Conceptualization, É.K.; formal analysis, P.P.; investigation, P.P.; methodology, P.P. and M.K.; project administration, É.K.; supervision, M.K., Á.G., and É.K.; validation, M.K., Á.G., and É.K.; visualization, P.P. and M.K.; writing—original draft, P.P.; writing—review and editing, M.K., Á.G., and É.K. All authors have read and agreed to the published version of the manuscript.

Funding: This research was funded by the AquaSpace Project (Ecosystem Approach to making Space for Aquaculture), grant number 633476.

Acknowledgments: We highly appreciate the help and methodological advice of Eszter Kovács (Szent-István University) and Eszter Kelemen (ESSRG). We are also grateful for our key-informants from the Körös-Maros National Park Directorate, Kiskunsági National Park Directorate, Agropoint Ltd., Biharugra Fish farm Ltd., BirdLife Hungary, the Birdwatching Centre in Biharugra, Öko2000 Ltd., and SzegedFish Ltd., for sharing their knowledge and perceptions with us.

Conflicts of Interest: The authors declare no conflicts of interest.

\section{References}

1. FAO. The State of World Fisheries and Aquaculture-Meeting the Sustainable Development Goals; FAO: Rome, Italy, 2018.

2. Duarte, C.M.; Wu, J.; Xiao, X.; Bruhn, A.; Krause-Jensen, D. Can Seaweed Farming Play a Role in Climate Change Mitigation and Adaptation? Front. Mar. Sci. 2017, 4, 100. [CrossRef]

3. MEA. Ecosystems and Human Well-being: Synthesis; Island Press: Washington, DC, USA, 2005.

4. Díaz, S.; Demissew, S.; Carabias, J.; Joly, C.; Lonsdale, M.; Ash, N.; Larigauderie, A.; Adhikari, J.R.; Aricò, S.; Báldi, A.; et al. The IPBES Conceptual Framework-Connecting nature and people. Curr. Opin. Environ. Sustain. 2015, 14, 1-16. [CrossRef]

5. FAO. Aquaculture Development 4. Ecosystem Approach to Aquaculture; FAO Technical Guidelines for Responsible Fisheries No. 5; FAO: Rome, Italy, 2010.

6. CBD. The Ecosystem Approach; Secretariat of the Convention on Biological Diversity: Montreal, QU, Canada, 2004.

7. Willot, P.-A.; Aubin, J.; Salles, J.-M.; Wilfart, A. Ecosystem service framework and typology for an ecosystem approach to aquaculture. Aquacultures 2019, 512, 734260. [CrossRef]

8. Haines-Young, R.; Potschin, M.B. Common International Classification of Ecosystem Services (CICES) V5.1 and Guidance on the Application of the Revised Structure; Fabis Consulting Ltd.: Nottingham, UK, 2018.

9. Aubin, J.; Rey-Valette, H.; Mathé, S.; Wilfart, A.; Legendre, M.; Slembrouck, J.; Chia, E.; Masson, G.; Callier, M.; Blancheton, J.; et al. Guide for Implementing Ecological Intensification of Aquaculture Systems; INRA: Rennes, France, 2014.

10. Barange, M.; Bahri, T.; Beveridge, M.C.M.; Cochrane, K.L.; Funge-Smith, S.; Poulain, F. Impacts of Climate Change on Fisheries and Aquaculture: Synthesis of Current Knowledge, Adaptation and Mitigation Options; Fisheries and Aquaculture Technical Paper No. 627; FAO: Rome, Italy, 2018.

11. Mitsch, W.J.; Gosselink, J.G. Wetlands, 3rd ed.; John Wiley \& Sons: New York, NY, USA, 2000.

12. Rounsevell, M.; Fischer, M.; Torre-Marin Rando, A.; Mader, A. The IPBES Regional Assessment Report on Biodiversity and Ecosystem Services for Europe and Central Asia; Secretariat of the Intergovernmental Science-Policy Platform on Biodiversity and Ecosystem Services: Bonn, Germany, 2018.

13. De Silva, S.S.; Soto, D. Climate change and aquaculture: Potential impacts, adaptation and mitigation. In Climate Change Implications for Fisheries and Aquaculture: Overview of Current Scientific Knowledge; Fisheries and Aquaculture Technical Paper. No. 530; Cochrane, K., De Young, C., Soto, D., Bahri, T., Eds.; FAO: Rome, Italy, 2009; pp. 151-212.

14. Junk, W.J.; An, S.; Finlayson, M.; Gopal, B.; Květ, J.; Mitchell, S.A.; Mitsch, W.J.; Robarts, R.D. Current state of knowledge regarding the world's wetlands and their future under global climate change: A synthesis. Aquat. Sci. 2012, 75, 151-167. [CrossRef]

15. Hunter, M.L. A Mesofilter Conservation Strategy to Complement Fine and Coarse Filters. Conserv. Biol. 2005, 19, 1025-1029. [CrossRef] 
16. Mushet, D.M.; Calhoun, A.J.K.; Alexander, L.C.; Cohen, M.J.; DeKeyser, E.S.; Fowler, L.; Lane, C.R.; Lang, M.; Rains, M.C.; Walls, S.C. Geographically Isolated Wetlands: Rethinking a Misnomer. Wetlands 2015, 35, 423-431. [CrossRef]

17. Hill, M.J.; Hassall, C.; Oertli, B.; Fahrig, L.; Robson, B.; Biggs, J.; Samways, M.; Usio, N.; Takamura, N.; Krishnaswamy, J.; et al. New policy directions for global pond conservation. Conserv. Lett. 2018, 11, e12447. [CrossRef]

18. Huang, J.; Zhang, Y.; Arhonditsis, G.; Gao, J.; Chen, Q.; Wu, N.; Dong, F.; Shi, W. How successful are the restoration efforts of China's lakes and reservoirs? Environ. Int. 2019, 123, 96-103. [CrossRef]

19. Naylor, R.L.; Goldburg, R.J.; Primavera, J.H.; Kautsky, N.; Beveridge, M.C.M.; Clay, J.; Folke, C.; Lubchenco, J.; Mooney, H.; Troell, M. Effect of aquaculture on world fish supplies. Nature 2000, 405, 1017-1024. [CrossRef]

20. Guidance on Aquaculture and Natura 2000. Sustainable Aquaculture Activities in the Context of the Natura 2000 Network. Available online: https:/ec.europa.eu/fisheries/sites/fisheries/files/docs/body/guidanceaquaculture-natura2000.pdf (accessed on 5 November 2019).

21. Walton, M.E.M.; Vilas, C.; Cañavate, J.P.; González-Ortegón, E.; Prieto, A.; Van Bergeijk, S.; Green, A.; Librero, M.; Mazuelos, N.; Le Vay, L. A model for the future: Ecosystem services provided by the aquaculture activities of Veta la Palma, Southern Spain. Aquaculture 2015, 448, 382-390. [CrossRef]

22. Alleway, H.K.; Gillies, C.L.; Bishop, M.J.; Gentry, R.R.; Theuerkauf, S.J.; Jones, R. The Ecosystem Services of Marine Aquaculture: Valuing Benefits to People and Nature. Bioscience 2018, 69, 59-68. [CrossRef]

23. Gentry, R.R.; Alleway, H.K.; Bishop, M.J.; Gillies, C.L.; Waters, T.; Jones, R. Exploring the potential for marine aquaculture to contribute to ecosystem services. Rev. Aquac. 2019, 12, 499-512. [CrossRef]

24. Yang, W.; Chang, S.X.; Xu, B.; Peng, C.; Ge, Y. Ecosystem service value assessment for constructed wetlands: A case study in Hangzhou, China. Ecol. Econ. 2008, 68, 116-125. [CrossRef]

25. Turkowski, K.; Lirski, A. Non-productive functions of fish ponds and their possible economic evaluation. In Carp Culture in Europe. Current Status, Problems, Perspectives Proceedings of International Carp Conference, Olsztyn, Poland, 15-16 September 2011; Lirski, A., Pyć, A., Eds.; Instytut Rybactwa Śródlądowego (IRŚ): Olsztyn, Poland, 2011; pp. 25-42.

26. Schmitt, L.H.M.; Brugere, C. Capturing Ecosystem Services, Stakeholders' Preferences and Trade-Offs in Coastal Aquaculture Decisions: A Bayesian Belief Network Application. PLoS ONE 2013, 8, e75956. [CrossRef] [PubMed]

27. Blayac, T.; Mathe, S.; Rey-Valette, H.; Fontaine, P. Perceptions of the services provided by pond fish farming in Lorraine (France). Ecol. Econ. 2014, 108, 115-123. [CrossRef]

28. Custódio, M.; Villasante, S.; Calado, R.; Lillebø, A. Valuation of Ecosystem Services to promote sustainable aquaculture practices. Rev. Aquac. 2019, 12, 392-405. [CrossRef]

29. Folke, C. Traditional Knowledge in Social-Ecological Systems. Ecol. Soc. 2004, 9, 7. [CrossRef]

30. Salerno, F.; Cuccillato, E.; Caroli, P.; Bajracharya, B.; Manfredi, E.C.; Viviano, G.; Thakuri, S.; Flury, B.; Basani, M.; Giannino, F.; et al. Experience With a Hard and Soft Participatory Modeling Framework for Social-ecological System Management in Mount Everest (Nepal) and K2 (Pakistan) Protected Areas. Mt. Res. Dev. 2010, 30, 80-93. [CrossRef]

31. Saxena, K.G.; Rao, K.; Sen, K.K.C.; Maikhuri, R.K.; Semwal, R.L. Integrated Natural Resource Management: Approaches and Lessons from the Himalaya. Conserv. Ecol. 2002, 5, 14. [CrossRef]

32. Narayan, D. Toward Participatory Research; World Bank Technical Paper Number 307; World Bank: Washington, DC, USA, 1996.

33. Bernard, H.R. Social Research Methods: Qualitative and Quantitative Approaches, 2nd ed.; Sage Publications: Thousand Oaks, CA, USA, 2013.

34. Kronenberg, J. Environmental impacts of the use of ecosystem services: Case study of birdwatching. Environ. Manag. 2014, 54, 617-630. [CrossRef]

35. Kiss, G. Statistical Reports - Catch Report-Year 2018; NAIK Research Institute of Agricultural Economics: Budapest, Hungary, 2019. (In Hungarian)

36. Haltenyésztés. Available online: https://regi.tankonyvtar.hu/hu/tartalom/tamop425/0059_haltenyesztes/ index.html (accessed on 16 March 2020). (In Hungarian) 
37. Edwards, P. Environmental issues in integrated agriculture-aquaculture and wastewater-fed fish culture systems. In Environment and Aquaculture in Developing Countries, Proceedings of ICLARM Conference, Bellagio, Italy, 1990; Pullin, R.S.V., Rosenthal, M., Maclean, J.L., Eds.; International Center for Living Aquatic Resources Management (ICLARM): Manila, Philippines, 1992; pp. 139-170.

38. Edwards, P.; Pullin, R.S.V.; Gartner, J.A. Research and Education for the Development of Integrated Crop-Livestock-Fishfarming Systems in the Tropics; ICLARM Studies and Reviews 16; International Center for Living Aquatic Resources Management: Manila, Philippines, 1988.

39. Oláh, J.; Pekár, F.; Váradi, L. Extensive Aquaculture and Ecotouristical Developments, a Case Study from the Biharugra Fishpond System; Birdlife Hungary: Budapest, Hungary, 2009. (In Hungarian)

40. Newing, H.; Eagle, C.M.; Puri, R.K.; Watson, C.W. Conducting Research in Conservation: Social Science Methods and Practice; Routledge Taylor Francis Group: London, UK; New York, NY, USA, 2011.

41. Kleiman, M.B.; Schutt, R.K.; Baily, C.A.; Czaja, R.; Blair, J.; Maisel, R.; Persell, C.H. Investigating the Social World: The Process and Practice of Research A Guide to Field Research Designing Surveys: A Guide to Decisions and Procedures How Sampling Works. Teach. Sociol. 1997, 25, 83. [CrossRef]

42. Kerepeczki, É.; Gyalog, G.; Halasi-Kovács, B.; Gál, D.; Pekár, F. Ecological values and functions of extensive fishponds. In Halászatfejlesztés; Kerepeczki, É., Bozánné Békefi, E., Gyalog, G., Lehoczky, I., Eds.; National Agricultural Research and Innovation Center-Research Institute for Fisheries and Aquaculture: Szarvas, Hungary, 2011; Volume 33, pp. 47-54. (In Hungarian)

43. Babbie, E.R. The Practice of Social Research, 13th ed.; Wadsworth Cengage Learning: Belmont, NY, USA, 2013; pp. 323-355.

44. Patton, M.Q. Qualitative Research and Evaluation Methods; Sage Publications: Thousand Oaks, CA, USA, 2002.

45. SRA Ethics Guidelines. Available online: https://the-sra.org.uk/SRA/Resources/Good-practice/SRA/ Resources/Good-Practice.aspx?hkey=ccb6430d-24a0-4229-8074-637d54e97a5d (accessed on 29 October 2019).

46. Rodríguez, J.P.; Beard, J.T.D.; Bennett, E.M.; Cumming, G.S.; Cork, S.J.; Agard, J.; Dobson, A.P.; Peterson, G.D. Trade-offs across Space, Time, and Ecosystem Services. Ecol. Soc. 2006, 11, 28. [CrossRef]

47. Raudsepp-Hearne, C.; Peterson, G.D.; Bennett, E.M. Ecosystem service bundles for analyzing tradeoffs in diverse landscapes. Proc. Natl. Acad. Sci. USA 2010, 107, 5242-5247. [CrossRef] [PubMed]

48. Chen, W.; He, B.; Nover, D.; Lu, H.; Liu, J.; Sun, W.; Chen, W. Farm ponds in southern China: Challenges and solutions for conserving a neglected wetland ecosystem. Sci. Total Environ. 2018, 659, 1322-1334. [CrossRef] [PubMed]

49. Broyer, J.; Richier, S.; Boullard, C.; Blottière, E. Fish farming abandonment and pond use by ducks breeding in Sologne (Central France). Eur. J. Wildl. Res. 2016, 62, 325-332. [CrossRef]

50. Marzano, M.; Carss, D.; Cheyne, I. Managing European cormorant-fisheries conflicts: Problems, practicalities and policy. Fish. Manag. Ecol. 2013, 20, 401-413. [CrossRef]

51. Behrens, V.; Rauschmayer, F.; Wittmer, H. Managing international 'problem' species: Why pan-European cormorant management is so difficult. Environ. Conserv. 2008, 35, 55-63. [CrossRef]

52. Nassl, M.; Löffler, J. Ecosystem services in coupled social-ecological systems: Closing the cycle of service provision and societal feedback. Ambiology 2015, 44, 737-749. [CrossRef]

53. Kari, S.; Korhonen-Kurki, K. Framing local outcomes of biodiversity conservation through ecosystem services: A case study from Ranomafana, Madagascar. Ecosyst. Serv. 2013, 3, e32-e39. [CrossRef]

54. Kovács, E.; Kelemen, E.; Kalóczkai, Á.; Margóczi, K.; Pataki, G.; Gébert, J.; Málovics, G.; Balázs, B.; Roboz, Á.; Mihók, B. Understanding the links between ecosystem service trade-offs and conflicts in protected areas. Ecosyst. Serv. 2015, 12, 117-127. [CrossRef]

55. Willemen, L.; Drakou, E.; Dunbar, M.B.; Mayaux, P.; Egoh, B.N. Safeguarding ecosystem services and livelihoods: Understanding the impact of conservation strategies on benefit flows to society. Ecosyst. Serv. 2013, 4, 95-103. [CrossRef]

56. Felipe-Lucia, M.R.; Comín, F.A.; Escalera-Reyes, J. A framework for the social valuation of ecosystem services. Ambio 2014, 44, 308-318. [CrossRef] [PubMed]

57. Non-Monetary Techniques for the Valuation of Ecosystem Service. Available online: http://www.opennessproject.eu/library/reference-book/sp-non-monetary-valuation (accessed on 15 June 2020).

58. Integrating Stakeholder Perspectives into Environmental Planning through Social Valuation of Ecosystem services: Guidance and Prototype Applications. Available online: https://oppla.eu/sites/default/files/uploads/ synthesisscvaluationmarch2017.pdf (accessed on 2 January 2019). 
59. Castro, A.J.; Martín-López, B.; Garcia-Llorente, M.; Aguilera, P.A.; López, E.; Cabello, J. Social preferences regarding the delivery of ecosystem services in a semiarid Mediterranean region. J. Arid. Environ. 2011, 75, 1201-1208. [CrossRef]

60. Howe, C.; Suich, H.; Vira, B.; Mace, G.M. Creating win-wins from trade-offs? Ecosystem services for human well-being: A meta-analysis of ecosystem service trade-offs and synergies in the real world. Glob. Environ. Chang. 2014, 28, 263-275. [CrossRef]

61. West, P. Conservation Is Our Government Now; Duke University Press: Durham, NC, USA, 2006.

62. Mugari, E.; Masundire, H.; Bolaane, M.; New, M. Perceptions of ecosystem services provision performance in the face of climate change among communities in Bobirwa sub-district, Botswana. Int. J. Clim. Chang. Strat. Manag. 2019, 11, 265-288. [CrossRef]

63. Musakwa, W.; Mpofu, E.; Nyathi, N.A. Local Community Perceptions on Landscape Change, Ecosystem Services, Climate Change, and Livelihoods in Gonarezhou National Park, Zimbabwe. Sustainability 2020, 12, 4610. [CrossRef]

(C) 2020 by the authors. Licensee MDPI, Basel, Switzerland. This article is an open access article distributed under the terms and conditions of the Creative Commons Attribution (CC BY) license (http://creativecommons.org/licenses/by/4.0/). 